\title{
Comparison of Elementary Students' Images of Science Teaching for Turkish, Dutch, Scottish, and German Science Classrooms
}

\author{
Hakan Turkmen ${ }^{1, *}$, Elif Unver ${ }^{2}$ \\ ${ }^{1}$ Faculty of Education, Ege Üniversitesi, Izmir, Turkey \\ ${ }^{2}$ Özel TAKEV Okulu, Turkey
}

Copyright $\bigcirc 2018$ by authors, all rights reserved. Authors agree that this article remains permanently open access under the terms of the Creative Commons Attribution License 4.0 International License

\begin{abstract}
The Draw-A-Science -Teacher-Test Checklist (DASTT-C) is an useful instrument to show how our science teaching environment and science teacher behaviors have been going on. This study is a cross cultural and comparative study to contribute to literature of problems of science teacher behaviors and of science learning environment. The purpose of this study is to investigate Turkish, Scottish, Dutch and German elementary students' images of science teachers and science teaching environment and to compare Turkish science teaching environment with other three countries. 128 elementary students from four different countries have joined this study in order to collect data. The results from the study have showed that Turkish elementary students' perspectives of science teaching style is $4.5 \%$ student-centered, $36.4 \%$ between student- teacher-centered, and $59.1 \%$ teacher-centered. The Scottish elementary students' perspectives of science teaching style is $38.6 \%$ student-centered, $52.3 \%$ between student- teacher-centered, and $9.1 \%$ teacher-centered. The Dutch elementary students' perspectives of science teaching style is $25 \%$ student-centered, $50 \%$ between student- teacher-centered, and $25 \%$ teacher-centered. The German elementary students' perspectives of science teaching style is $24 \%$ student-centered, $55 \%$ between student- teacher-centered, and $21 \%$ teacher-centered.
\end{abstract}

Keywords Science Education, DASTT-C

\section{Introduction}

Todays' perspective of science lesson is to make our students scientifically literate, because students are able to use scientific knowledge learned at school in order to solve their own problems and help other people in their lives.
Memorizing of scientific theories or facts is not a very important skill anymore in the modern countries leading in education. Kids can reach scientific facts or information anytime and everywhere by many ways (Yılmaz, et al. [29]). To catch up with the modern world many countries are undertaking reforms of their education systems. The modern education systems tell us we, as educators, do not educate our kids in the views of industrial societies and economies of $19^{\text {th }}$ and $20^{\text {th }}$ centuries which has generated winners and losers based on students' academic achievement and a standardized curriculum. It says oppositely that students should think differently and more flexibly and use their innate capacity for curiosity, creativity and critical thinking called higher order skills to be productive people for their society. Thus, many countries revised their education system in the light of number of significant intellectual movements which are contextual, dialectical, empirical, technological, STEM-A, nature of science and socio-historical movements (Turkmen\& Pedersen [25]).

Many developed western countries aware of necessity of their educational perspective began to revise their science education curriculum and program in the 1990's, such as the USA, the UK, Turkey, the Netherlands, Scotland and Germany. This solid necessity comes from the international research studies, such as TIMSS and PISA results. Nobody can say these types of international research studies' results define the education system of the country is good or bad or is better than others but, at least, these results give us a clue to assume whether or not there is a problem in the education system of the country and also to think why our students were not successful in these international research studies.

Draw-A-Science-Teacher-Test Checklist (DASTT-C) is useful to show how our science lesson is and should via elementary students' point of view. Drawing test instrument was firstly developed as original Draw-A Man- 
test by Goodenough (1926) then Chamber modified it as Draw -A-Scientist-Test (DAST) which measured children's perceptions of scientists' (1983). It assessed the children's drawings according to seven basic standard image elements. Then DAST was adapted to analyze science lessons. The main concept of DASTT-C is a listing of teacher-centered and student- centered attributes of an elementary science teacher rather than a scientist (Carner, et al [4]; [5]; [21]; [22]; [24] ).

There are many studies to evaluate their science learning and teaching perspectives especially using with DASTT-C in the literature.

In Germany, Markic, et al. [11] evaluated 104 students in science teaching department conceptions using DASTT-C. They found that secondary chemistry and physics students in science teaching were teacher-centered views about science teaching and learning.

Markic \& Eilks [12] showed that 266 first-year science education students from four separate German universities drawings revealed that physics students thought were $11.1 \%$ student-centered, $8.9 \%$ neither student nor teacher-centered, $80 \%$ teacher-centered; chemistry students thought were $27.5 \%$ student-centered, $6.3 \%$ neither student nor teacher-centered, $66.3 \%$ teacher-centered; biology students thought were $11.1 \%$ student-centered, $8.9 \%$ neither student nor teacher-centered, $80 \%$ teacher-centered; primary school students thought were $74.2 \%$ student-centered, 9.1\% neither student nor teacher-centered, $16.7 \%$ teacher-centered. The results say students in science teaching points out more student-centered beliefs than chemistry and physics science students. According to Markic and Eilks [13] , one of the possibilities of this result might be that preference for a specific teaching style changes with respect to specific discipline. Another similar study from Markic and Eilks [13] showed that the German system is based on a bottom-up teacher training style. Three different groups of chemistry student teachers were studied and the data showed that student teachers' beliefs decreased dramatically during their university education from teacher-centered beliefs in the beginning to more student-centered beliefs by the end.

While evaluating teachers' curricular beliefs in the Netherlands, Van Driel, et al.[28] found that Dutch chemistry teachers most often believed that the main goal of teaching was to introduce students to the fundamental concepts and skills within chemistry so as to prepare them for future training in chemistry.

Recently, Dutch students perform well but rarely excellent in International studies, Trends in International Mathematics and Science Study (TIMMS), Progress in International Reading Literacy Study (PIRLS), Programme for International Student Assessment (PISA) into science education.

The science perspective was added into the curriculum of Scottish primary schools in the 1960s and it is part of Environmental Studies. According to Harlen, \& Holroyd [9] "Existing research into teachers' confidence by Whittaker (1980) and by Wragg, et al. (1989) and Bennett et al. (1992) and into understanding of various concepts by Summers and colleagues at Oxford (Summers and Kruger 1992) revealed that many teachers not only lacked confidence and perceived competence to teach science but indeed retained many misconceptions found in school pupils $(1997,93)$. The Office for Standards in Education (OFSTED) [16] report for science in primary schools highlighted that teachers need to use more inquiry approach in science lessons. The Scottish Survey of Achievement Science report declared that primary when science teachers were teaching their confidence were fairly or fewer confident about teaching (Scottish Government, [19]). Although there have not found and study done using with DATT-C, other studies related teaching science and the Scottish results in the TIMSS report in December 2008 had highlighted failings in math and science in Scotland's schools. These types of results made necessary the Scottish Government to respond with Science and Engineering 21 An Action Plan for Education, focusing student-centered teaching and learning of science, engineering and technology, and encourage students to consider a career in science and engineering and raise public understanding of science.

Table 1. OECD. Pisa 2009-12-15, Pisa Results in Focus

\begin{tabular}{|c|c|c|c|c|c|}
\hline & Population 2016 & $\begin{array}{c}\text { wealthiest country in } \\
\text { the world in 2014 }\end{array}$ & $\begin{array}{c}\text { PISA 2009 results } \\
\text { of science }\end{array}$ & $\begin{array}{c}\text { PISA 2012 results } \\
\text { of science }\end{array}$ & $\begin{array}{c}\text { PISA 2015 results } \\
\text { of science }\end{array}$ \\
\hline The Netherlands & 16.9 million & 16 th & 11 th & 14 th & 17 th \\
\hline German & 80.6 million & 19 th & 13 th & 12 th & 16 th \\
\hline Scotland & 5.5 million & 21th with UK & 16th with UK & 21th with UK & 15 th with UK \\
\hline Turkey & 79.4 million & 70th & 43th & 43th & 52 th \\
\hline
\end{tabular}


In Turkey, Unal and Akpinar [26] observed 19 teachers in their classes and reported that almost $20 \%$ of science teachers were in a transitional period, while the other $80 \%$ of science teachers presented teacher-centered instruction. Turkish teachers are mostly in a transition process from teacher-centered instruction to student-centered instruction. According to Yilmaz, et al. [29], student-centered science teaching perspective was $20 \%$, teacher-centered science teaching perspective was $39 \%$, and between student-centered and teacher-centered was $41 \%$, according to per-service teachers' results. On the other hand, Elmas, et al. [8] study showed pre-service chemistry teachers' perspective of science teaching style is $37.9 \%$ student-centered, $22.7 \%$ teacher-centered, and $39.4 \%$ reflect the characteristics of both student-centered and teacher-centered approaches. Uner, et. al. [27] showed $40 \%$ of participants were rated as student-centered, $5 \%$ of participants were rated as teacher-centered and $55 \%$ of participants were rated as between student-centered and teacher-centered. Another study from Tatar, et al. [20] showed that pre-service science teachers' mental models of science teaching is $22 \%$ student-centered, $17 \%$ teacher-centered, and $61 \%$ reflect the characteristics of both student-centered and teacher-centered approaches. Akkuş [1], showed 130 preservice secondary science teachers' (biology, chemistry and physics) images is $24.62 \%$ student-centred, $53.85 \%$ between student and teacher-centred, and $21.4 \%$ teacher-centred teaching style approaches. Duban [7], found that $13.08 \%$ of pre-service teachers' images are student-centred, $24.30 \%$ of pre-service teachers' images are teacher-centered, $62.62 \%$ of pre-service teachers' images are between student-centered and teacher-centered science teaching. Buldur [3] studied with 76 pre-service teachers as freshman, sophomore, junior and senior students. Freshmen' drawings were rated as $6.3 \%$ student-centred, $22.4 \%$ between student-centered and teacher-centered, $72.4 \%$ teacher-centred; sophomores' drawings were rated as $15.8 \%$ student-centred, $42.1 \%$ between student-centered and teacher-centered, $42.1 \%$ teacher-centred; juniors' drawings were rated as $51.3 \%$ student-centred $42.1 \%$ between student-centered and teacher-centered, $6.6 \%$ teacher-centred; seniors' drawings were rated as $67.1 \%$ student-centered, $30.3 \%$ between student-centered and teacher-centered, $2.6 \%$ teacher-centred. According to Aydogdu and Selanik-Ay [2] study 100 primary school teachers' drawings showed that $8 \%$ of drawings is rated as Student-centered; \% 36 of drawings is rated as teacher-centered; $56 \%$ of drawings is rated as between student-centered and teacher-centered

\section{Method}

\section{Instrument}

In this study, the DASTT-C was a primary instrument to collect data from students. Students were instructed to "Draw a picture of you as a science teacher at work. Also they draw "What is the teacher doing" and "What are the students doing?" regarding their drawings. The instrument includes three sections,

Teacher, consisting of 2 subsections, "teacher's activity" and "teacher's positions" and 5 check list points;

Student, consisting of 2 subsections, "student's activity" and "student's position"; and 3 check list points,

Environment, including 5 subsections, "desks arranged in rows", "teacher desk", "lab organization", "symbols of teaching", and "symbols of science knowledge".

Researcher checked whether an element is displayed or not in the each subsections in students drawings. Each element in each subsection of the instrument is considered by the instrument's developers to depict stereotypical elements of teaching and classroom images. If a stereotypical element appears in a student's drawings, that element on the checklist is marked by researcher. Total checklist scores can range from 0 to 13 . Scores are grouped into three ranges on a continuum, with scores of $0-4$ representative of student-centered teaching style, 10-13 representative of teacher-centered teaching style, and 5-9 representative of neither student-centered nor teacher-centered teaching style (appendix A, B, C).

\section{Subject}

One hundred twenty eight (128) elementary students are from four different countries; 44 students from Turkey, 20 students from the Netherlands, 44 students from Scotland, 20 students from Germany, for this study. All students are 9-10 years old (see table 2)

Table 2. Demographic information of students

\begin{tabular}{|c|c|c|c|}
\hline Turkish & Dutch & Scottish & German \\
\hline 44 & 20 & 44 & 20 \\
\hline
\end{tabular}

\section{Research Question/Design}

The study focused on the question, "What mental images do elementary students have of themselves as science teachers?" The DASTT-C was administered to the elementary students at the end of the first semesters. As instructors, we only gave one directions "Draw a picture of yourself as a science teacher at work" (Thomas, et al. [23]; [24]).The DASTT-C took 30-40 minutes to complete.

\section{Analyzing the Data}

In this study, 128 elementary students' drawings were assessed using the DASTT-C and categorized along a continuum from student-centered to teacher-centered in orientation.

Many students saw their science teacher as active not 
sitting in the science classroom. For most science teacher, safety is first. None draw science museums, outdoor learning environments.

\section{Teacher Patterns}

Twenty four Turkish elementary students drew themselves as a science teacher were talking and giving directions to the class $(54 \%)$ and twenty teachers were demonstrating experiment (46\%). As visual aids, forty teachers were using computer, projector, smartboard, and charts $(91 \%)$. Forty were standing in front of the students or behind the table or chalkboards $(91 \%)$ and thirty six teachers were centrally located in the classroom (82\%)

Twelve Dutch elementary students drew themselves as a science teacher were talking and giving directions to the class $(60 \%)$, eight teachers demonstrating experiment $(40 \%)$. As visual aids, all twenty teachers were using computer, projector, smartboard, and charts (100\%). Nineteen teachers were standing $(96 \%)$ in front of the table or chalkboards, half of them were centrally located in the classroom $(50 \%)$

Eleven Scottish elementary students drew themselves as a science teacher were talking and giving directions to the class $(25 \%)$, thirty three were demonstrating experiment $(75 \%)$. As visual aids, forty two teachers were using computer, projector, smartboard, and charts (97\%). Forty one were standing in front of the table or chalkboards and were centrally located in the classroom (96\%).

Nine German elementary students drew themselves as a science teacher talking and giving directions to the class $9(45 \%)$, eleven teachers were demonstrating experiment (55\%). As visual aids, all teachers were using computer, projector, smartboard, and charts $(100 \%)$ and half of them were standing behind the table or chalkboards $(100 \%)$ (see table 3)

\section{Students Patterns}

In most pictures, while teachers were talking or lecturing, 20 Turkish students were watching and listening (77\%) and ten were responding the questions or talking with teacher (23 \%). In thirty six Turkish students' drawings, students were sitting $(82 \%)$. For Dutch students, twelve students were watching and listening $(60 \%)$ and eight students were responding the questions or talking with teachers (40\%). In ten students' drawings, students were sitting (50\%). For Scottish students, ten students were watching and listening $(23 \%)$ and thirty four students were responding the questions or talking with teachers $(77 \%)$. In twenty two students' drawings, students were sitting (50\%). For German students, eight students were watching and listening (40\%) and twelve students were responding the questions or talking with teachers $(60 \%)$. In eight students' drawings, students were sitting (50\%) (see table 4).

Table 3. Teacher patterns data for four countries

\begin{tabular}{|c|c|c|c|c|c|}
\hline \multicolumn{2}{|c|}{ Teacher Pattern } & Turkish & Dutch & Scottish & German \\
\hline \multirow{4}{*}{ Activity } & Demonstrating Experiment/ Activity & $20(46 \%)$ & $12(60 \%)$ & $33(75 \%)$ & $11(55 \%)$ \\
\cline { 2 - 6 } & Lecturing/Giving Directions (teacher talking) & $24(54 \%)$ & $8(40 \%)$ & $11(25 \%)$ & $9(45 \%)$ \\
\cline { 2 - 6 } & Using Visual Aids (chalkboard, overhead, and charts) & $40(91 \%)$ & $20(100 \%)$ & $42(97 \%)$ & $20(100 \%)$ \\
\hline \multirow{3}{*}{ Position } & Centrally located (head of class) & $36(82 \%)$ & $10(50 \%)$ & $41(96 \%)$ & $8(40 \%)$ \\
\cline { 2 - 6 } & Erect Posture (not sitting or bending down) & $40(91 \%)$ & $19(96 \%)$ & $41(96 \%)$ & $20(100 \%)$ \\
\hline
\end{tabular}

Table 4. Students patterns data for four country

\begin{tabular}{|c|c|c|c|c|c|}
\hline \multicolumn{2}{|c|}{ Students pattern } & Turkish & Dutch & Scottish & German \\
\hline \multirow{3}{*}{ activity } & $\begin{array}{c}\text { Watching and listening (or so suggested by } \\
\text { teacher behavior) }\end{array}$ & $34(77 \%)$ & $12(60 \%)$ & $10(23 \%)$ & $8(40 \%)$ \\
\cline { 2 - 6 } & Responding teacher/text questions & $10(23 \%)$ & $8(40 \%)$ & $34(77 \%)$ & $12(60 \%)$ \\
\hline \multirow{2}{*}{ Position } & Seated (or suggested by classroom furniture) & $36(82 \%)$ & $10(50 \%)$ & $22(50 \%)$ & $8(40 \%)$ \\
\hline
\end{tabular}




\section{Learning Environment Patterns}

According to students drawings the element of the desk arrange in rows were drawn $91 \%$ by Turks, $40 \%$ by Dutch's, 32\% by Scotties, and 35\% by Germans; teachers table position was drawn $61 \%$ by Turks), $60 \%$ by Dutch's, $46 \%$ by Scotties and $50 \%$ by Germans. These two elements one of the sign of teacher-centered teaching perspective and Turkish drawing could be categorized as teacher-centered teaching. But the other drawings from three countries could be categorized as student-centered teaching classroom design. Lab organization was drawn $86 \%$ by Turkish, $60 \%$ by Dutch, $65 \%$ by German, and $68 \%$ by Scottish students. The symbols of teaching and science knowledge were drawn $79 \%$ and $84 \%$ by Turkish, $70 \%$ and $45 \%$ by Dutch, $82 \%$ and $68 \%$ by Scottish, $60 \%$ and $60 \%$ by German students. All drawings from four countries were high percentage. Science teaching without lab activities, symbols and experiments unacceptable thought in all students (Table 5).

In most pictures, students drew test tubes, skeleton model as lap equipment. It would seem that they link this typical piece of lab equipment with teaching and learning science. Moreover, students drew interesting indication about science subjects on the chalkboard. For example, many students drew firstly is lab safety but there were not seen this indication in Turkish students' drawings.

The DASTT-C represents, if the scores between 10-13 is teacher-centered, if between $0-4$ is student-centered, if between 5-9 is neither teacher-centered nor student-centered, which tell us there is changing teaching environment through student-centered or teacher-centered. As seen figure 1, all 13 indication showed that Turkish science lessons is generally teacher-centered, Scottish science lessons is students-centered, German and Dutch lessons are neither teacher-centered nor student-centered..

Table 5. Environment Pattern

\begin{tabular}{|c|c|c|c|}
\hline Inside of classroom & Turkish & Dutch & Scottish \\
\hline Desk arrangement in rows & $40(91 \%)$ & $8(40 \%)$ & $14(32 \%)$ \\
\hline Teacher table in front of room & $27(61 \%)$ & $12(60 \%)$ & $20(46 \%)$ \\
\hline Lab. organization & $38(86 \%)$ & $12(60 \%)$ & $30(68 \%)$ \\
\hline Symbols of teaching & $35(79 \%)$ & $14(70 \%)$ & $36(82 \%)$ \\
\hline Symbols of science knowledge & $37(84 \%)$ & $9(45 \%)$ & $30(68 \%)$ \\
\hline
\end{tabular}

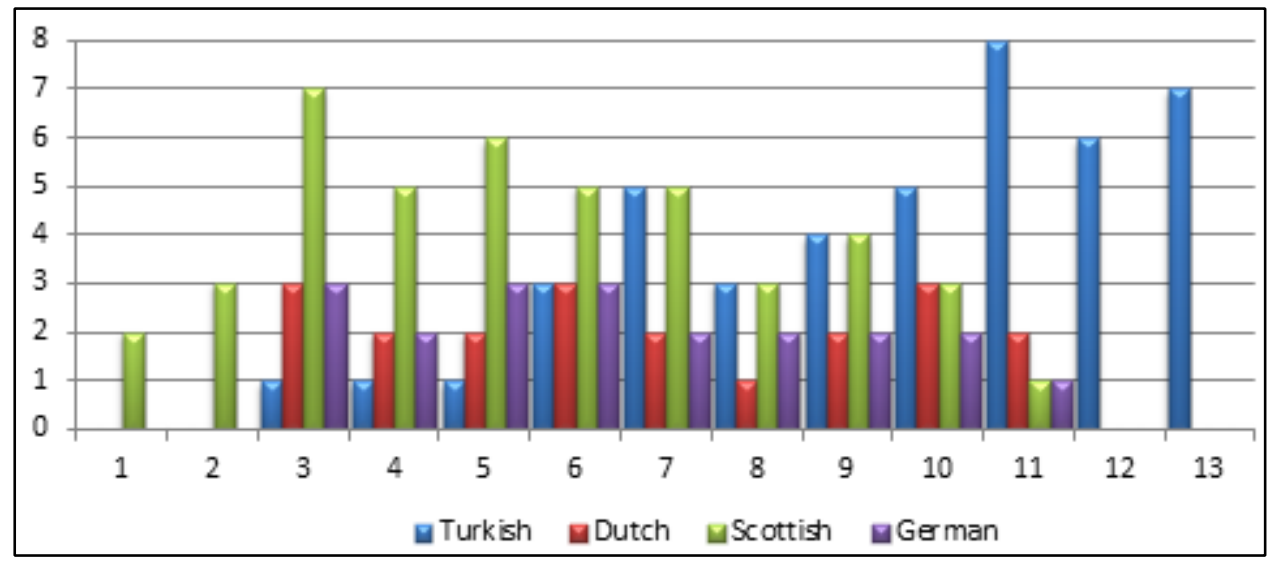

Figure 1. Four countries' elementary students' DASTT-C frequency 
In figure 2, The DASTT-C results categorized for four countries. Turkish elementary students' perspective of science teaching style is $4.5 \%$ student-centered, $59.1 \%$ teacher-centered, and $36.4 \%$ between student- centered and teacher-centered. The results of study showed that Scottish elementary students' perspective of science teaching style is $38.6 \%$ student-centered, $9.1 \%$ teacher-centered, and $52.3 \%$ between student- centered and teacher-centered. Dutch students' perspective of science teaching style is $25 \%$ student-centered, $25 \%$ teacher-centered, and $50 \%$ between student- centered and teacher-centered. German students' perspective of science teaching style is $24 \%$ student-centered, $21 \%$ teacher-centered, and 55\% between student- centered and teacher-centered. German and Dutch students' results are so close, but Scottish students' results much better than others and Turkish students' results are worst among all

In the drawings representing teacher-centered teaching style (10-13 scores), students listen carefully their teachers and work alone. The teacher is talking, showing, writing on board, and directing learning activities. Teachers introduce a topic of science, prepare students and teach them how to do an experiment. The classroom remains orderly. Students are quiet, are not allowed to express themselves, ask questions, meaning no speaking balloon drawn. Here four examples from each country students' draws (see Figure 3).

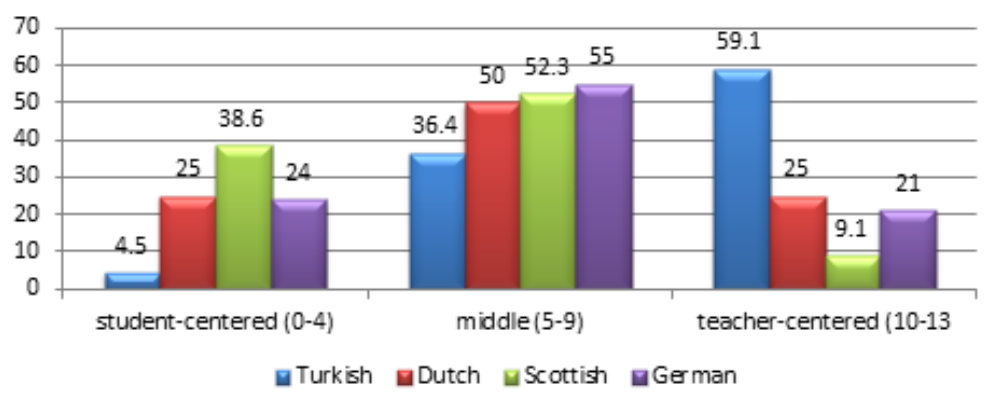

Figure 2. Four countries' elementary student' DASTT-C percentage

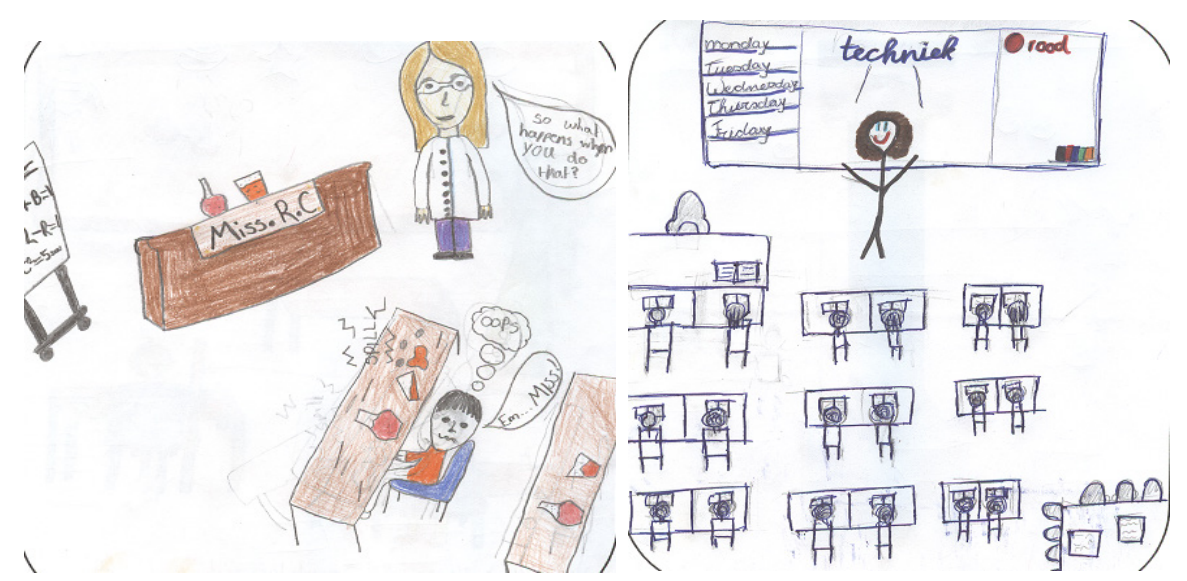

Example of Scottish draw

Example of Dutch draw

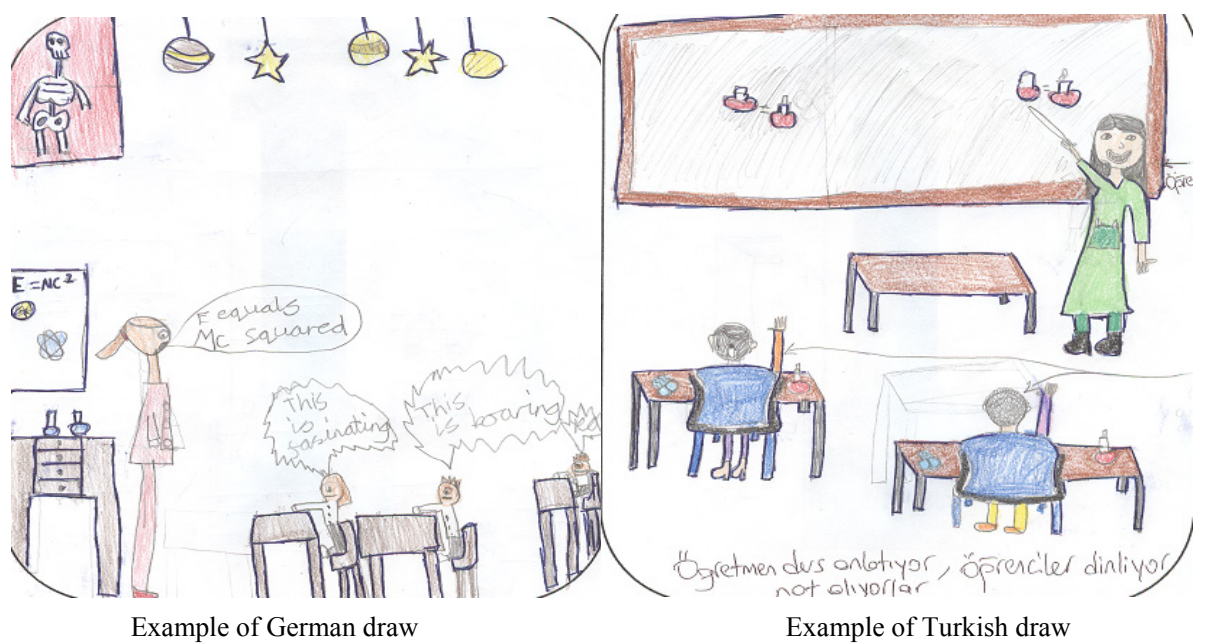

Figure 3. Examples of teacher-centered draws. 
What is the teacher doing? What are the students doing?

"Teacher is doing an experiment, which is prepared by him, in front of the class and giving instruction of how to do the experiment to his students."

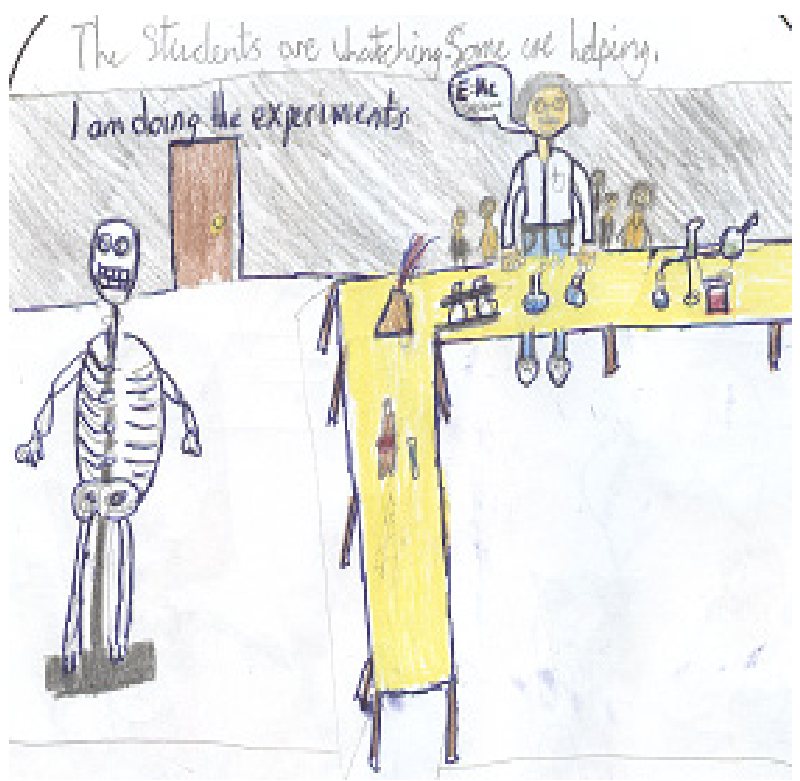

Example of Scottish draw
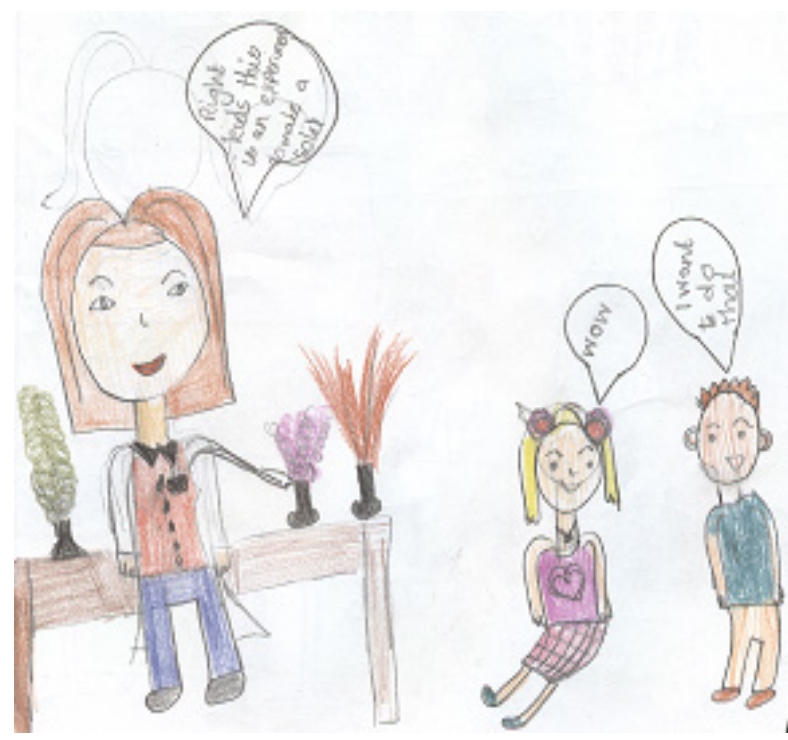

Example of German draw
In the middle range of scores (5-9), it can be seen that students are doing same experiments with same materials, being led by teachers. Students are raising their hands to ask question or answer questions and actively doing an experiment leading and/or assisting by teacher (Figure 4).

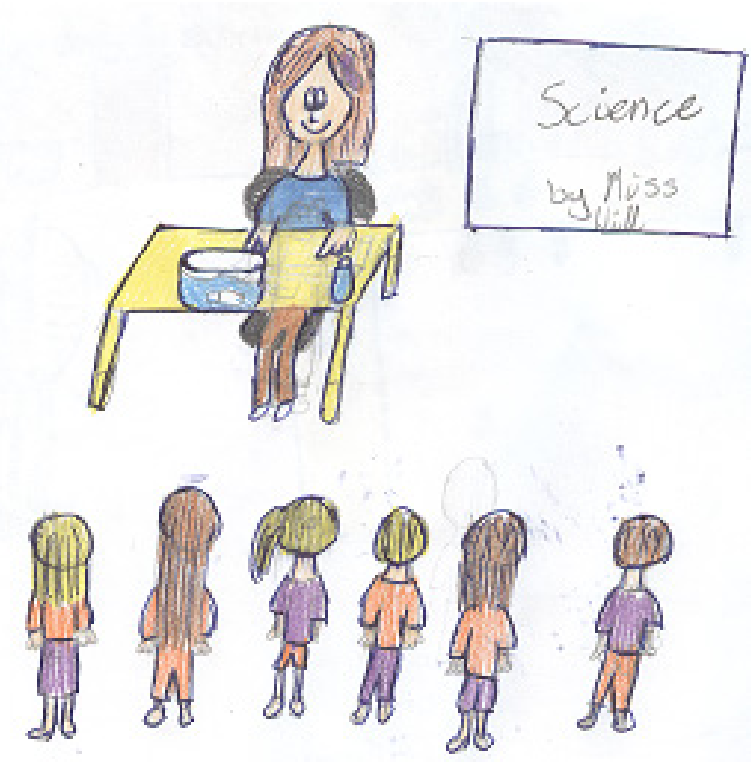

Figure 4. Examples of No-decision draws. (Scottish- Dutch-German-Turkish) 
What is the teacher doing? What are the students doing?

"When the students are doing experiment, Firstly teacher is warning be careful by the way assisting, asking questions about experiment to them. Students are listening, responding to her questions."

Student-centered images (0-4) indicates a constructivist learning environment where students are actively joining lesson and participating cooperatively at different tables and/or the teacher is checking all groups of students and/or standing with one group of students while other group of students are doing experiment at a different tables (Figure 5).

What is the teacher doing? What are the students doing?

"Teacher is watching the students who are studying science projects on the computer. And also teacher assisting about what the students' needs. Students can do their robots in class. The students are searching their data, and compare their data after searching and make conclusion."

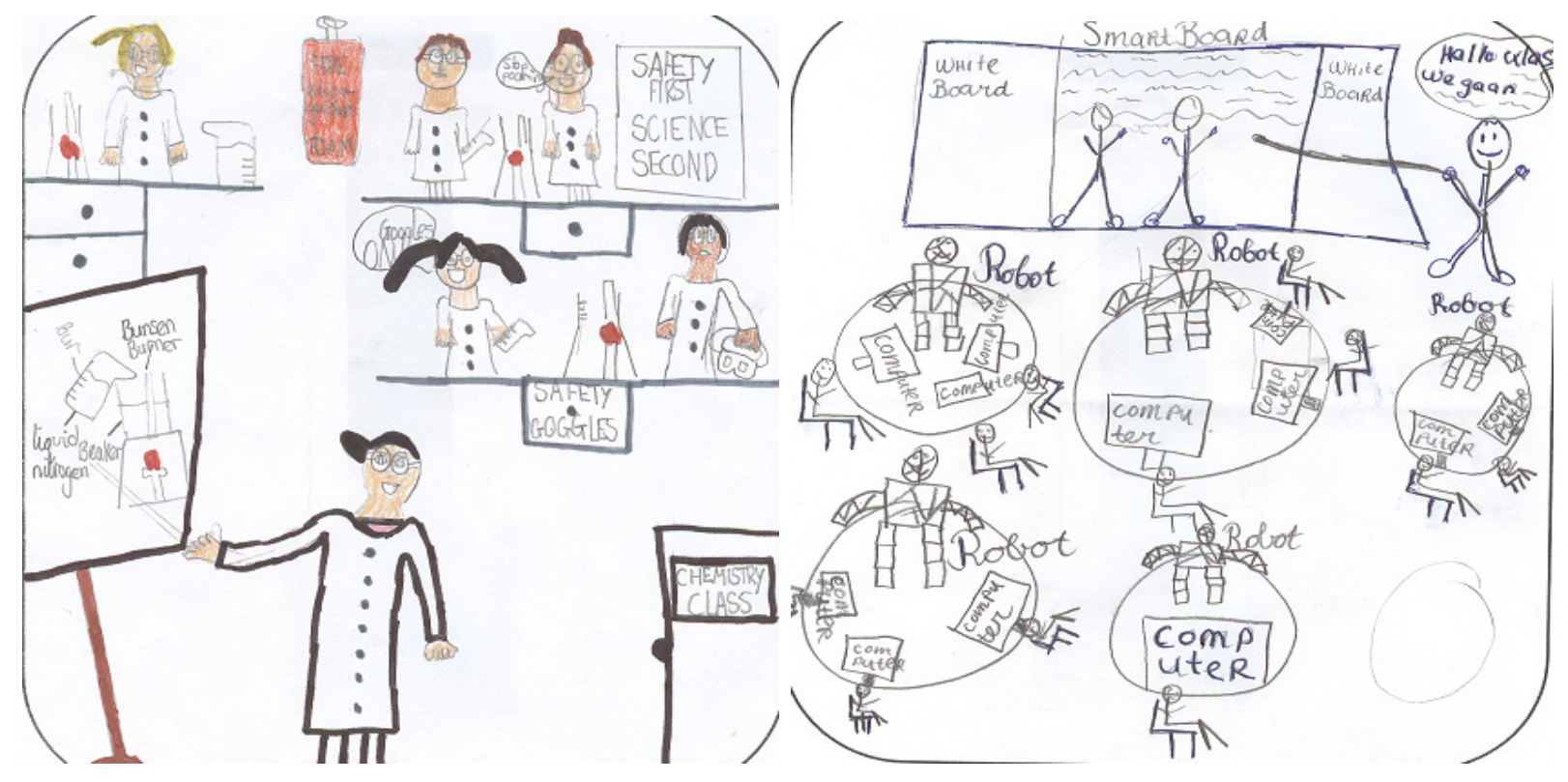

Example of Scottish draw

Example of Dutch draw

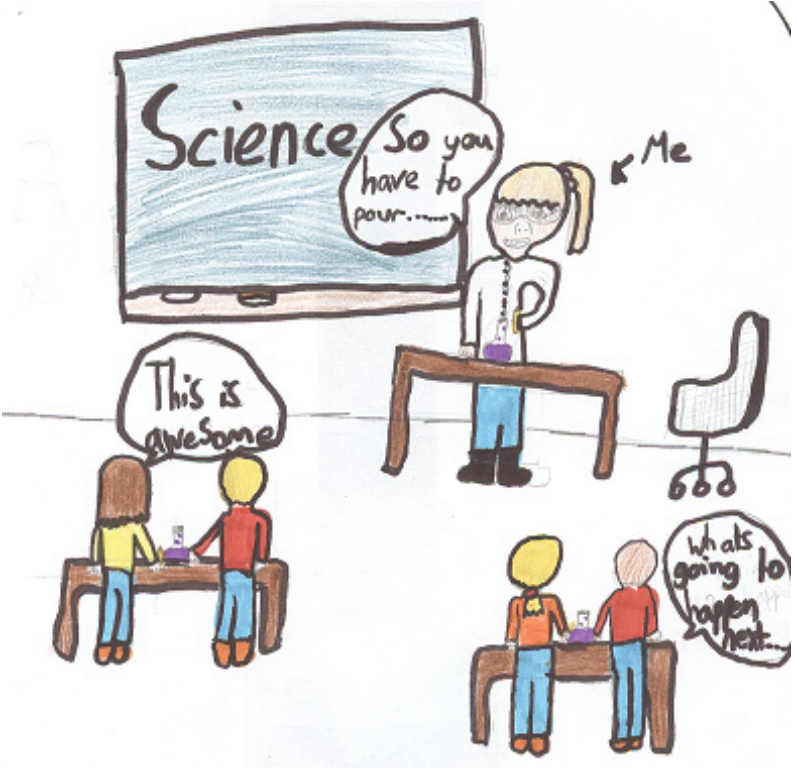

Example of German draw

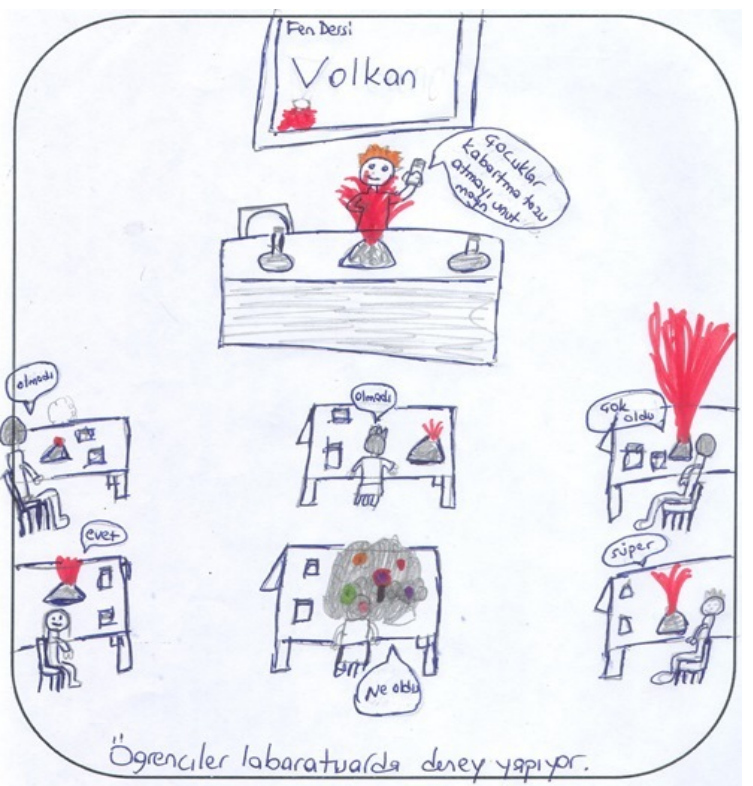

Example of Turkish draw

Figure 5. Examples of Student-Centered draws (Scottish- Dutch-German-Turkish) 


\section{Conclusion and Recommendation}

This research is cross cultural study applying four different countries to see Turkish science teaching environment and compare with other three countries, Germany, Scotland and the Netherlands. Of course this research results cannot be generalized for whole countries because of data was not gathered from whole population of countries. But, at least, the results give us opportunity to see what education goes on and some obstacles in front of students' educational life.

According to results, Scottish students' thoughts are the highest of their science learning environment related student-centered. German and Dutch students' perspective about science learning environment are almost same (25\%-24\%) and all of three, Scottish, German, and Dutch, rates of neither student nor teacher-centered are very close. We can say that there is changing teaching environment through student-centered by effect of their reform movements. Although Turkey wanted to revise their educational perspective in the light of modern projects and theories, Turkish students' drawing did not show us same rise. Teacher-centered rate is $\% 59.1$ and very higher than others. There is not much change from the researches done by Unal and Akpinar [26], Y1lmaz et. al [29] to now. There might be many reason why Turkish elementary students lack constructivism and inquiry integration in their educational experiences, but it is clear that reform movements and spending much money have not affect Turkish education.

There is correlation between DATT-C results and PISA results. Last three PISA results showed German, Dutch and Scottish ranks are very close and in the top 10 to 20 but Turkish ranks are back of top. As limited studies in Turkey, something has to be changed in Turkish education if she wants to catch up modern countries.

Based on results, we can say some salient recommendations to catch up modern countries.

Educational dynamics, Council of Higher Education, Academics, Ministry of Education and Educational Social Unions, must work together to make decisions in a same positive scientific way.

For teacher education at the universities, school practice must be based on constructivist and inquiry perspective.

Further study of elementary, secondary and high school students, using the DASTT-C as a pre/post assessment of the students' who learning science in order to investigate the whether any change in students' perceptions will be useful for researchers, administers, politics.

The DASTT-C should be applies in different regions of countries to able to generalize perspective of the countries.

\section{REFERENCES}

[1] Akkuş, H. (2013) Pre-Service Secondary Science Teachers'
Images about themselves as science teachers. Journal of Baltic Science Education, 12(2), 249-260

[2] Aydogdu, B. \& Selanik-Ay, T. (2016). Determination of teacher characteristics which support constructivist learning environments. Eurasian Journal of Educational, 63, 293-310.

[3] Buldur, S. (2017). A longitudinal investigation of the preservice science teachers' beliefs about science teaching during a science teacher training programme. International Journal of Science Education, 39(1), 1-19.

[4] Carnes, G. N. (2003). Interpreting Elementary Teacher Candidates' Images of Science Teaching. Proceedings of the Hawaii International Conference of the Association for the Education of Teachers in Science. Available on CD ; ISBN 1541-5880

[5] Carnes, G. N., Brown, S., Munn, W., \& Schull, T. (2002). Interacting with M.A.T. interns about their views of science teaching. in P.A. Rubba, J.A. Rye, B. Crawford, \& W. J. DiBaise (Eds.). Proceedings for the 2002 Annual International Conference of the Association for the Education of Teachers in Science.

[6] Chambers, D. W. (1983). Stereotypic images of the scientist: The Draw-A-Scientist Test. Science Education, 67(2), 255-265.

[7] Duban, N.Y. (2013). Pre-Service Science and Technology Teachers' Mental Images of Science Teaching. Eurasian Journal of Educational Research, 50, 107-126.

[8] Elmas, R, Demirdöğen, B., \& Geban, Ö. (2011) Preservice Chemistry Teachers' Images about Science Teaching In Their Future Classrooms. Hacettepe Üniversitesi Eğitim Fakültesi Dergisi, 40, 164-175.

[9] Harlen, W., \& Holroyd, C. (1997) Primary teachers' understanding of concepts of science: impact on confidence and teaching, International Journal of Science Education, 19(1), 93-105.

[10] Louca, P., Rigas, P., \& Valanides, N. (2002). Primary Student Teachers' Conceptions of Science Teaching, A. Papastylianou (Ed.), Proceedings of the 2nd International Conference on Science Education. Nicosia, Cyprus, ARLO, Ltd, Cyprus, 242-248.

[11] Markic, S., Valanides, N. \& Eilks, I. (2005). First-year science student teachers' images of science teaching in Germany. Paper presented at the 5 th European Science Education Research Association conference, Barcelona (Spain), 28 August - 1 September 2005.

[12] Markic, S., \& Eilks, I.( 2008). A Case Study on German First Year Chemistry Student Teachers Beliefs about Chemistry Teaching, and Their Comparison with Student Teachers from Other Science Teaching Domains. Chemistry Education Research and Practice 9 (1): 25-34

[13] Markic, S., \& Eilks, I. (2011). Die Veränderung fachbezogener Vorstellungen angehender Chemielehrkräfte über Unterricht während der Ausbildung - eine Cross Level Studie [The change in domain-specific beliefs about teaching and learning of prospective chemistry teachers during their teacher education - a cross level study]. Chemie konkret, 18, 14-19. 
[14] OECD. Pisa 2015, Pisa Results in Focus. Retrieved December 17, 2016 from https://www.oecd.org/pisa/pisa-2015-results-in-focus.pdf

[15] OECD. Trends Shaping Education 2016. Retrieved November 21, 2016 from $\mathrm{http} / / /$ www.oecd.org/edu/trends-shaping-education-221870 49.htm

[16] OFSTED (2004) OFSTED subject reports 2002/03: science in primary schools (London, OFSTED).

[17] Pedersen, J.E., \& Thomas, J. (1999). Draw-A-Science-Tea cher Checklist: Children's Perceptions of Teaching Science. A paper presented at the National Association for Research in Science Teaching Conference, Boston.

[18] Science and Engineering Education Advisory Group, (2012) Supporting Scotland's STEM education and culture: Second Report. [Available online] http://www.scotland.gov.uk/Resource/0038/00388616.pdf (last accessed 10/05/2013

[19] Scottish Government (2008). 2007 Scottish Survey of Achievement (SSA) Science, Science Literacy and Core Skills. [Available online]

http://www.scotland.gov.uk/Resource/Doc/226080/006121 3.pdf (Last viewed 27/11/2014).

[20] Tatar. N.,Yildiz Feyzioğlu, E., Buldur, S., \& Akpinar, E. (2012). Pre-Service Science Teachers' Mental Models about Science Teaching. Educational Sciences: Theory \& Practice, 12(4), 2934-2940.

[21] Thomas, J. A., Pedersen, J. E. (1998a). Draw-a-Science teacher: A visualization of beliefs and self-efficacy. Paper presented at the annual meeting of the Association for the Education of Teachers in Science, Minneapolis, MN.

[22] Thomas, J. A., Pedersen, J. E. (1998b).
Draw-A-Science-Teacher-Test: Pre-service Elementary Teachers Perceptions of Classroom Experiences. A paper presented at the National Association of Researchers in Science Teaching international meeting, San Diego: California.

[23] Thomas, J. A., Pedersen, J. E. (2001). When Do Science Teachers Learn to Teach? A Comparison of School Children's and Pre-service Teachers' Science Teacher Illustrations. A paper presented at the Association for the Education of Teachers of Science annual meeting, Costa Mesa.

[24] Thomas, J. A., Pedersen, J. E., \& Finson, K. (2001). Validating the Draw-A-Science-Teacher- Test- Checklist (DASTT-C): Exploring mental models and teacher beliefs. Journal of Science Teacher Education, 12(4), 295-310.

[25] Turkmen, H., \& Pedersen, J.E. (2003). Learning environments in our classrooms: International student's perspectives. Science Education International. 14(1):5-10.

[26] Unal, G., \& Akpinar, E. (2006). To what extent science teachers are constructivist in their primary schools. Journal of Baltic Science Education, 2(10), 40-50.

[27] Uner, S., Akkuş, H. \& , Turan, N. (2012) Image yourself as a chemistry teacher. Procedia - Social and Behavioral Sciences, 47, 417-421.

[28] Van Driel, Jan H., Bulte, A. MW. ,Verloop, N. (2005) . The conceptions of chemistry teachers about teaching and learning in the context of a curriculum innovation. International Journal of Science Education, 27-3, 303-322.

[29] Yılmaz, H., Turkmen, H., Pedersen, J.E., \& Huyugüzel Cavas, P. (2007). Evaluation of pre-service teachers' images of science teaching in Turkey. Asia-Pacific Forum on Science Learning and Teaching, 8(1),1-20. 